\title{
An Investigation of Factors Impacting the Wellness of Academic Library Employees
}

\author{
Leo S. Lo and Bethany Herman
}

\begin{abstract}
The term "wellness" is fast garnering attention on how it affects one's professional and personal life. This study explores the multi-dimensions of wellness and investigates factors that might impact the "wellness" of employees in academic libraries. The research topic was addressed through quantitative analyses of responses to multiple choice, ranking and qualitative analyses of responses to open-ended items. With a total of 1123 respondents, key findings include: there are statistical relationships between how respondents characterize themselves and how often they felt overwhelmed; the respondents' age and how often they felt overwhelmed; the respondents' age and how important they feel eating healthy is; the respondents' current position and how important is being optimistic is to them.
\end{abstract}

\section{Introduction}

Feeling stressed or overwhelmed at work could negatively affect an individual's job satisfaction 1 and general well-being, and could in turn negatively affect the organization. As workers' health and general well-being suffer, companies have to spend more money on insurance premiums, which could then negatively impact their revenue and potentially lead to layoffs or even bankruptcies. According to the World Health

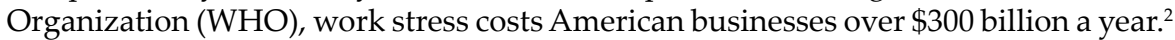
Therefore, "wellness" as a concept is garnering attention in the workplace.

Many employers are providing wellness support to their employees as means for combating illness-related loss of productivity due either to absenteeism or to reduced productivity while at work (presenteeism). ${ }^{3}$ These efforts comprise workplace wellness programs that focus primarily on the prevention of chronic disease, such as lifestyle risk factors and lifestyle management, and secondarily on improving disease control. Furthermore, "workplace wellness programs are a primary component of the Patient Protection and Affordable Care Act (PPACA) or healthcare reform law commonly referred to as the ACA. The ACA allows employers to reward workers who participate in wellness programs, and penalize those who refuse, with discounts or increases of as much as 30 percent of their insurance costs." ${ }^{4}$ As a result, many of the workplace wellness programs tend to focus on nutrition and weight management activities as well as

Leo S. Lo is Associate University Librarian at Old Dominion University Libraries; e-mail: llo@odu.edu. Bethany Herman is Public Services Librarian at Houston Community College; e-mail: bethany.herman@ hccs.edu. (C2017 Leo S. Lo and Bethany Herman, Attribution-NonCommercial (http://creativecommons. org/licenses/by-nc/4.0/) CC BY-NC. 
smoking cessation programs, ${ }^{5}$ as the benefits of health-focused wellness programs are more quantifiable in the balance sheets. Higher education institutions and, to a lesser degree, academic libraries are following this trend of workplace wellness programs.

The authors posit that, while physical wellness is an important aspect of a person's overall well-being, other dimensions of wellness are equally important and necessary and should not be neglected. The purpose of this research is to examine the following 1) whether library employees are feeling overwhelmed; 2 ) if so, what are the possible causes? 3) what actions are they taking to relieve the feeling? and 4) how much do library employees value the different dimensions of wellness and their behavior in achieving wellness in the different dimensions?

\section{Literature Review}

\section{Workplace Wellness}

Workplace wellness as a concept has been in existence since the 1970s. It was a movement of a gradual shift of healthcare responsibilities from the government and the healthcare industry to the employers and consumers. ${ }^{6}$ Even though it was generally acknowledged that wellness was a multidimensional concept, ${ }^{7}$ workplace wellness was primarily focused on health promotion, with the belief that health and fitness were the means to achieving overall wellness. This outlook of overall well-being could be traced back to some of the potential reasons for the development of worksite wellness programs in the first place. The occupational safety and health $(\mathrm{OSH})$ movement in the 1970s and the worksite health promotion movement (WHP) were cited as two reasons for the appearance of workplace wellness programs; these were meant to counter the deficiency in the healthcare system at the time. ${ }^{8}$ During this period, as research began to show the cost of unhealthy employee behaviors, a cultural shift about physical fitness contributed to the creation of workplace wellness programs. ${ }^{9}$ Health and fitness programs can benefit organizations in many financial and nonfinancial ways, such as reduced absenteeism, improved morale, lower insurance premium, increased productivity, reduced turnover, increased public relations, and more. ${ }^{10}$ However, subsequent evaluation of such programs over several years strongly suggested that simply focusing on healthy working conditions and general health education were not adequate to achieving a well life. ${ }^{11}$ So trends developed to build more comprehensive programs directed at changing the employee's "lifestyle." Such a change required personal motivation in addition to education. Ultimately, the wisdom went, a healthier lifestyle would lead to a higher quality of life, which would then translate to higher employee performance.

\section{Stress and Wellness in the Library Workplace}

According to psychologist Saqib Saddiq, working in a library is more stressful than being a firefighter or a policeman. ${ }^{12}$ His 2006 study surveyed 300 people from five occupations (firefighters, police officers, train operators, teachers, and librarians). Presented at a society conference in Glasgow, his data revealed that "librarians complained that there was not enough variety in their work, they did not have enough control over their careers, and they were not allowed to put their skills to full use. This lack of job satisfaction meant that they were more apt to be absent from work, or to be frustrated with their outside of work relationships."13 In the decade since his study, the job responsibilities of library workers have changed dramatically, and the 2006 stressors might not be as prominent for 2016 library workers. Another study, conducted in 2008/2009 in the United Kingdom, investigated workplace stress in a further education college library service. "Librarians reported that interaction with students can be stressful or enjoyable, depending on context. The need to control noise levels, 
modify student behaviour and balance the needs of different user groups are cited as stressors." 14 Another recent study surveyed librarians to identify possible stressors such as role ambiguity, role overload, perceived stress, burnout, life satisfaction, work withdrawal, and health conditions. The findings of the study showed that academic librarians largely reported role ambiguity and role overload as common stressors in the profession. ${ }^{15}$ The authors of that study defined "role ambiguity" as stemming from "unclear expectations about specific job-related responsibilities" and "role overload" as the perception of a job to be excessively demanding with the requirement to work harder, longer, and/or faster.

Wellness in academic libraries has been discussed in literature as an additional service that libraries can provide to their users. Some academic libraries have embraced the idea of wellness as a user service and outreach strategy in part because of their close connection to student life and student success on campus. Hinchliffe and Wong discuss using a "wellness wheel" approach for shifting an academic library's services to an integrative learning and student-centered endeavor. Possible ways of adopting a "wellness wheel" approach include partnering with other campus departments to bring wellness services into the library, developing collections to support a lay understanding of different wellness concepts, and creating wellness-related outreach focused on high-stress times in the academic calendar, such as finals week. ${ }^{16}$ Mills and Lodge suggest that information professionals use the concepts of Emotional Intelligence and an understanding of the information environment to create positive librarian-user interactions. ${ }^{17}$

However, when addressing wellness in the work of academic library workers, few studies have been published that holistically examine the ways workers, from students to top-level administration, view workplace wellness at their organization and that examine their own wellness beliefs and habits. One example of such a study focuses on the job satisfaction of professional and paraprofessional library staff at the University of North Carolina at Chapel Hill. The study notes that differences in levels of satisfaction largely suggest that academic library professionals are more satisfied than their paraprofessional counterparts in the areas of work enjoyment, coworkers, promotion, pay, and overall satisfaction. ${ }^{18}$

\section{Dimensions of Wellness}

Traditionally, the concept of wellness is viewed from two perspectives. The "clinical tradition" focuses on dealing with depression, anxiety, and stress, while the "psychological tradition" is about life satisfaction. ${ }^{19}$ Dr. Bill Hettler followed the "psychological tradition" of wellness and created a model of an "active process through which the individual becomes aware of and makes choices toward a more successful existence." 20 He maintained that "wellness" could be divided into 6 basic dimensions:

1) Intellectual wellness measures the degree to which one engages his or her mind in creative, stimulating mental activities. An intellectually well person uses the resources available to expand his or her knowledge in improved skills, along with expanding potential for sharing with others.

2) Emotional wellness measures the degree to which one has an awareness and acceptance for one's feelings. This includes the degree to which one feels positive and enthusiastic about oneself and life. It measures the capacity to appropriately control one's feelings and related behavior, including the realistic assessment of one's limitations.

3) Physical wellness measures the degree to which one maintains cardiovascular flexibility and strength; the behaviors that help one to prevent and detect early illnesses; and the degree to which one chooses foods that are consistent with the dietary goals as prescribed by physicians and nutritionists. 
4) Social wellness measures the degree to which one contributes to the common welfare of one's community.

5) Occupational wellness measures the satisfaction gained from one's work and the degree to which one is enriched by that work.

6) Spiritual wellness measures one's ongoing involvement in seeking meaning and purpose in human existence. It includes a deep appreciation for the depth and expanse of life and natural forces that exist in the universe. ${ }^{21}$

For this study, the concept of "wellness" will refer to this multifaceted definition of holistic wellness that focuses beyond the scope of physical health and illness prevention.

\section{Methods}

\section{Participants}

To reach a range of academic library employees, the survey was distributed to the e-mail lists and Facebook pages listed in appendix A. The invitation included an explanation of the survey, a statement of the goal of the project, and a hyperlink to the survey. The survey (see appendix B), which was administered through Qualtrics, included a consent form and 20 questions consisting of a mix of multiple choice, ranking, yes/no, and open-ended questions. Upon completion of the survey, participants were presented with a message thanking them for their time. The survey was active between January 17 and February 13, 2015. Of the 1,123 total respondents, 906 fully completed the survey. Participation in the survey was voluntary. As an incentive for completing the survey, participants were presented with the option to enter a drawing for one of two \$25 Amazon gift cards (provided out of personal funds of the co-investigators). Only respondents who chose to record their e-mail addresses in the survey were entered into the drawing. To protect respondents' confidentiality, all identifying information was stripped from responses before analysis, leaving no way to tie responses to a particular e-mail address. All other responses were completely anonymous. The survey instrument was approved by the Institutional Review Boards of University of Alabama, which was one of the researchers' institutions at the time of survey distribution.

\section{Survey Design}

The survey questionnaire began with a screening question that required respondents to indicate the type of library in which they worked. Respondents who do not work at academic libraries are directed to a thank-you message and the end of the survey. The research design of this study was nonexperimental. It sought to examine the correlational relationships of library employees' perceptions of wellness and their behavior contributing toward their well-being, as well as their outlook on life and demographic characteristics (such as age, gender, position in their organization, and the size of their libraries). An additional aim of the survey was to explore library employees' views of the role of academic libraries in promoting and providing wellness support to users and to explore some of the workplace wellness programs provided to the respondents. These data and results will be presented in a separate paper. The focus of this paper is on analyzing library employees' perception of wellness and their behavioral and perceptional aspects of the survey data.

\section{Results}

The research objective of this study was to investigate 1) whether library employees are feeling overwhelmed; 2 ) If so, what are the possible causes? What actions are they taking to relieve the feeling? and 3) How much do library employees value the different dimensions of wellness and their behavior in achieving wellness in the different dimensions? 
The survey begins with a screening question asking respondents to indicate what types of libraries they worked at. A total of 1,098 individuals responded. Respondents who selected "nonacademic" $(n=2)$ were directed to the end of the survey. Of the remaining respondents, 75 percent $(n=819)$ selected "four-year academic library", 11 percent $(n=126)$ selected "two-year academic," and 14 percent $(n=151)$ selected the "other academic library" option. This distribution is shown in figure 1.

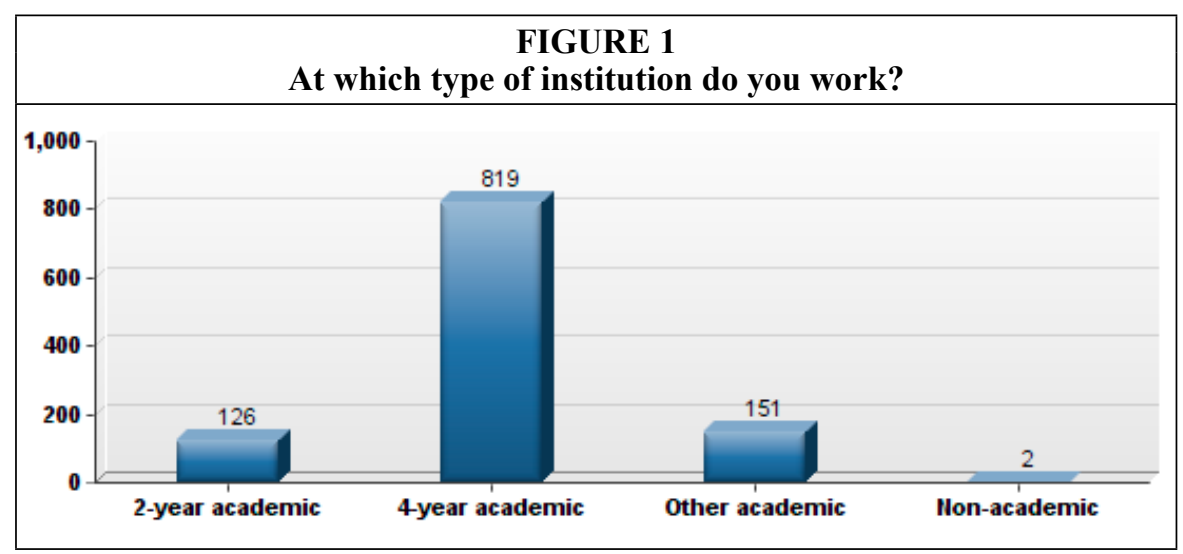

The survey identified respondents' current positions at their libraries. Of the 974 individuals who responded to this question, 72 percent $(n=697)$ indicated that they were in Professional Librarian positions, which was by far the largest group, followed by Administration $(16 \% ; n=151)$, and Support Staff $(10 \% ; n=96)$. A small percentage, 1 percent $(n=11)$ were Student Employees.

Respondents were also asked to indicate their gender and age. Of the 969 responses, 13 percent were Male $(n=128)$, and 87 percent were Female $(n=841)$; 4 percent were 25 years old and under $(n=34), 33$ percent were between 26 and 35 years old ( $n$ $=317), 24$ percent were between 36 and 45 years old $(n=235), 19$ percent were between 46 and 55 years old $(n=180)$, and 21 percent were 56 years old and over $(n=203)$. This distribution of respondents' age is shown in figure 2.

Respondents were asked to indicate how long they have worked in libraries. Of the 972 responses, 3 percent $(n=28)$ indicated less than 1 year. A total of 26 percent

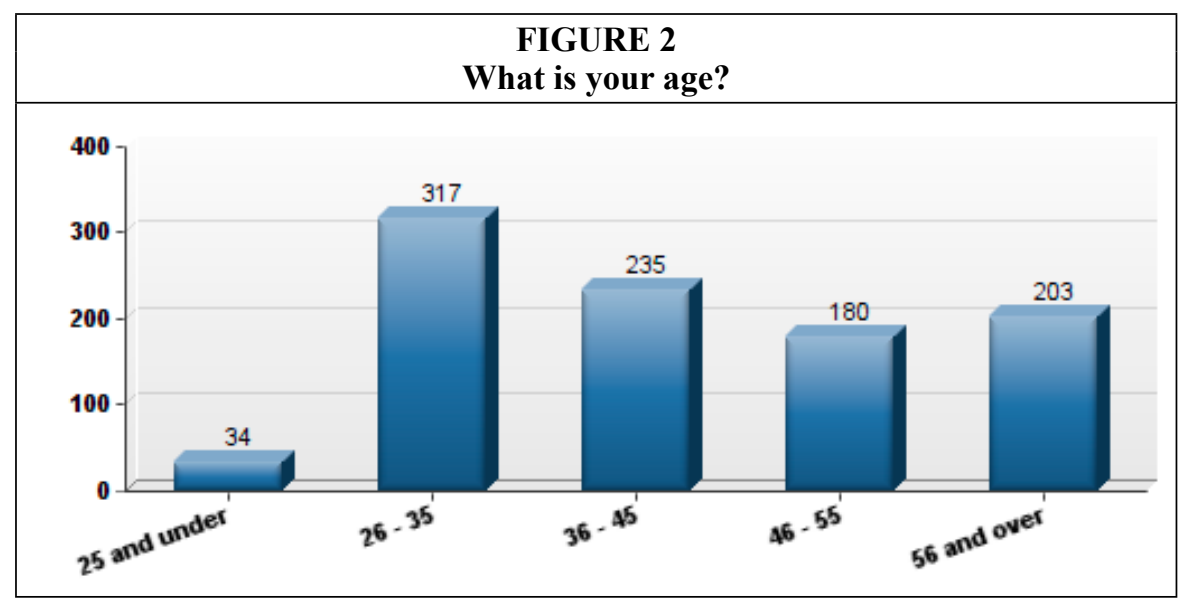


$(\mathrm{n}=254)$ replied that they have worked in libraries between 1 and 5 years; 21 percent $(n=207)$ have worked 6-10 years; and 14 percent $(n=136)$ have worked $11-15$ years. Finally, 36 percent $(n=347)$ have worked more than 15 years.

The survey asked respondents to indicate how optimistic or pessimistic they would characterize themselves. Out of 1,085 responses, only 1 percent $(n=8)$ characterize themselves as "very pessimistic," while a much larger percentage of the respondents $(18 \% ; n=199)$ characterized themselves as "very optimistic." Seventeen percent $(n=$ 180) characterized themselves as "somewhat pessimistic," and a similar percentage of people $(14 \%$; $=154)$ saw themselves as "neither pessimistic nor optimistic." The largest group of respondents $(50 \% ; n=544)$ saw themselves as "somewhat optimistic." This distribution is shown in figure 3.

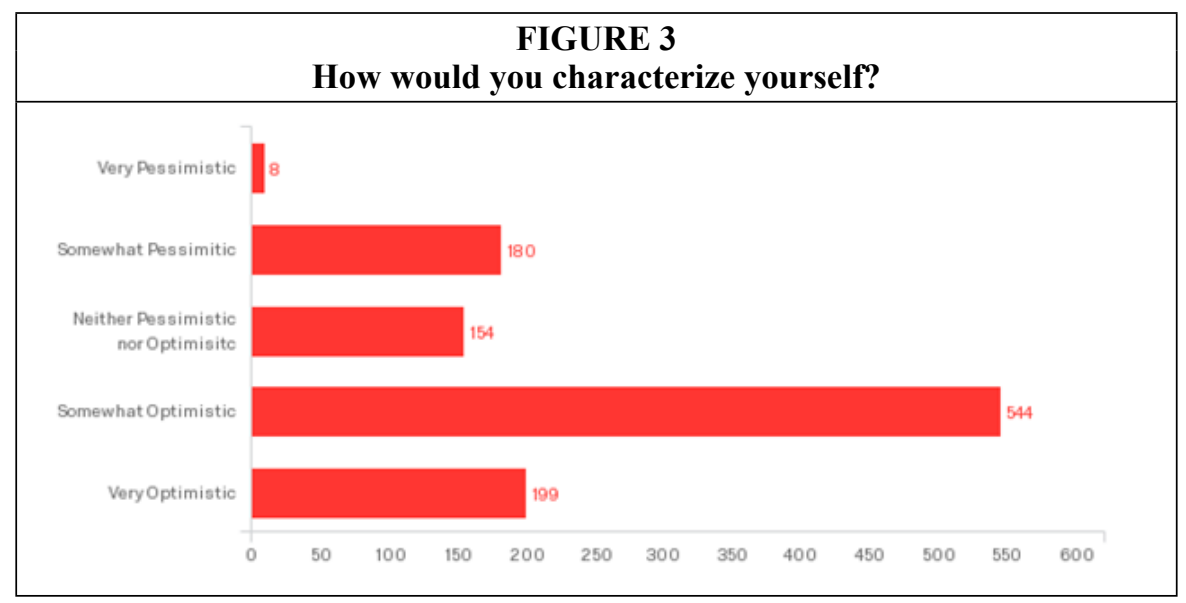

Respondents were asked how often they felt overwhelmed in the past 6 months. Out of 1,081 responses, the largest percentage $(48 \%$; $=524)$ answered "sometimes," followed by "frequently" $(34 \% ; n=370)$. Four percent $(n=45)$ reported that they always felt overwhelmed, while 12 percent $(n=129)$ rarely felt overwhelmed, and 1 percent $(n=$ 13) never felt overwhelmed in the past 6 months. This distribution is shown in figure 4.

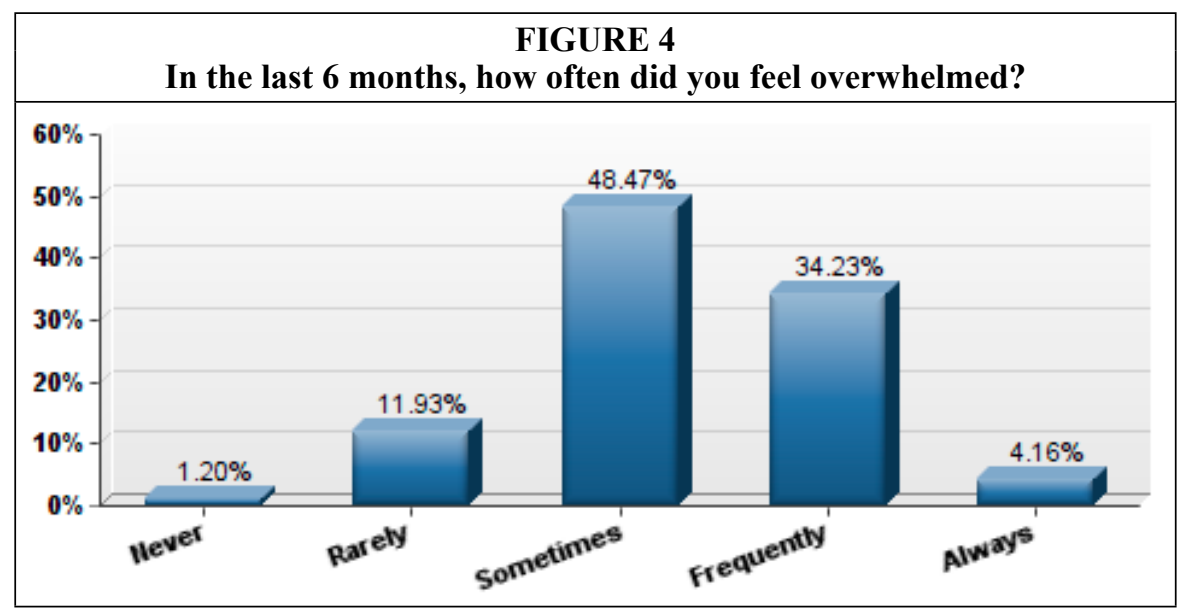


The survey then asked respondents to rank which of the following (Health, Family, Work, Life Fulfillment, Finance, and Other) typically overwhelmed them the most (" 1 " being the most overwhelming, and " 6 " being the least overwhelming). There were 1,003 responses to this question, and the largest number of respondents selected "Work" as the number one most overwhelming aspect $(n=455)$. A low mean value (0-6) indicates higher rankings of the aspect overall. "Work" has a mean value of 2.12, which is noticeably lower than all the other aspects ("Finance" $=3.11$; "Family" $=3.11$; "Life Fulfillment" = 3.45; "Health" = 3.49; and "Other" = 5.71).

Respondents were asked what they tend to do when they feel overwhelmed. A list of 22 choices were given, and the respondents were asked to select all that applied. A total of 1,035 respondents replied to this question. The number one answer was "Eat More" (49\%; n = 506), followed closely by "Avoid Social Interactions" (47\%; n = $491)$, and "Watch TV/Movies" (44\%; $n=460)$. "Eat Less Healthy $(40 \% ; n=418)$ and "Sleep Less" $(40 \% ; n=416)$ rounded up the top five responses. At the other end of the responses, answers with the fewest selection were mostly contradictory activities to the top five choices; they were therefore consistent with their overall results. The bottom five answers were "Smoke More" $(2 \% ; n=23)$, "Eat Healthier" $(3 \% ; n=35)$, "Eat Less $(7 \% ; n=74)$, “Socialize with Others" $(7 \% ; n=75)$, and Meditate $(9 \% ; n=95)$. This distribution is shown in figure 5.

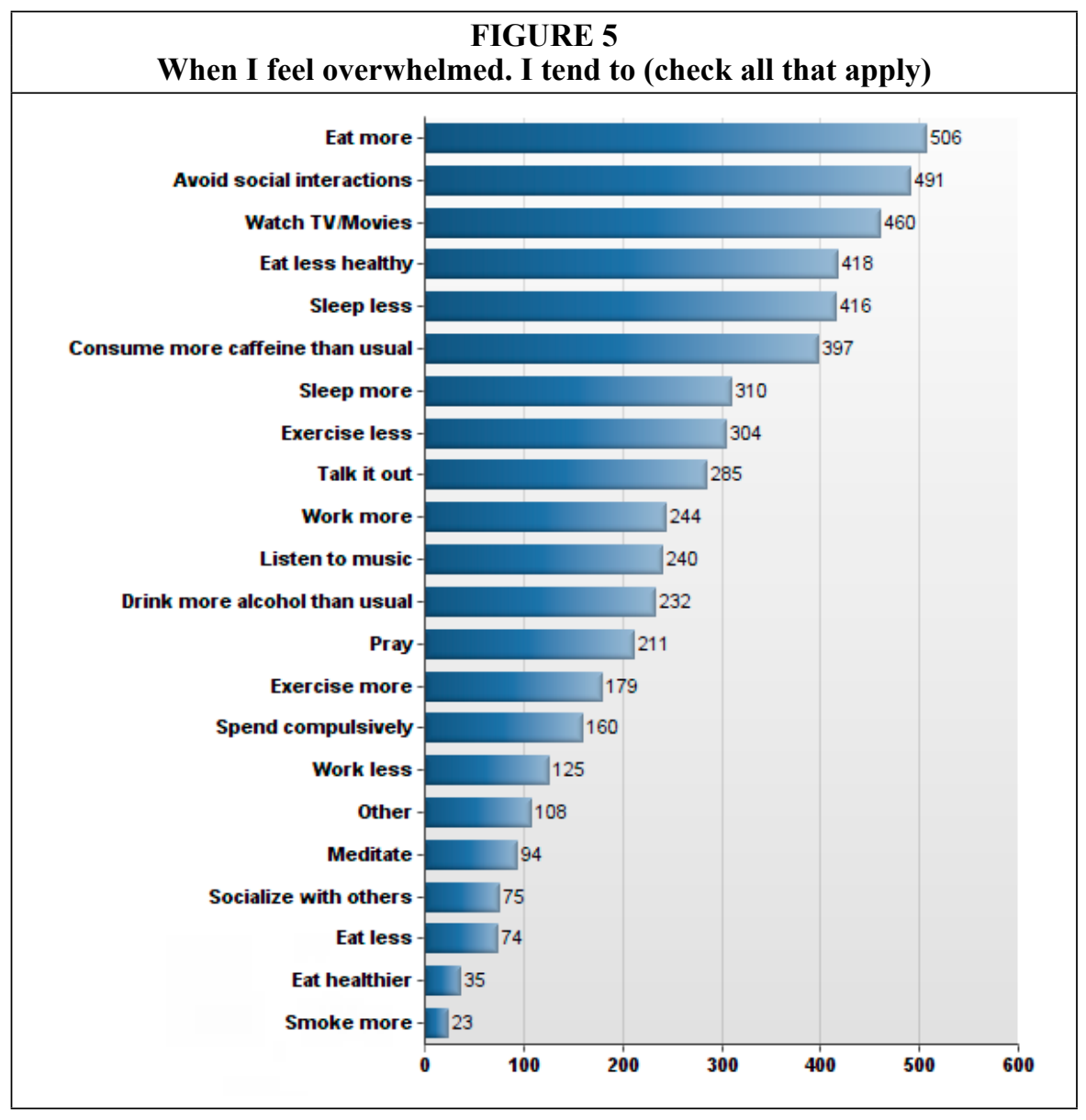


Next the researchers were interested in determining the importance of each wellness dimension to the respondents. The choices were: 1) Eating healthy (physical wellness); 2) Exercising regularly (physical wellness); 3) Pursuing continuing education for my career (occupational wellness); 4) Giving (social wellness); 5) Living consistently with my values and beliefs (spiritual wellness); 6) Being optimistic (emotional wellness); and 7) Challenging my mind with intellectual and creative pursuit (intellectual wellness).

Respondents were given five choices from "Very Important" (value =5) to "Not Very Important" (value $=1$ ). The middle three values were "Somewhat Important" (value =2), "Moderately Important" (value =3), and "Important" (value =4). As there is not negative importance, the authors used a unipolar five-point scale. The choices were presented at the top of a matrix table with increasing values from left to right. The endpoints of the response scale were maximally differentiated. The authors adhered to the common Likert scale practice of assigning "somewhat important" a lower value than "moderately important."22

A high mean value indicates respondents consider the activity important. Out of the seven activities, "Living consistently with my values and beliefs" has the highest mean value (4.19), followed closely by "Challenging my mind with intellectual and creative pursuit" (4.14) and "Eating healthy" (4.08). The activity with the lowest mean value is "Pursuing continuing education for my career" (3.38). The full table is shown in figure 6.

\begin{tabular}{|lc|}
\hline \multicolumn{2}{|c|}{ FIGURE 6 } \\
\hline & Mow important are these activities to you? \\
\hline Eating Healthy & 4.08 \\
Exercising regularly & 3.74 \\
Pursuing continuing education for my career (e.g. workshops, classes, etc) & 3.38 \\
Giving (e.g. contribute to the common welfare of our community, live in har... & 3.43 \\
Living consistently with my values and beliefs & 4.19 \\
Being Optimistic & 3.56 \\
Challenging my mind with intellectual and creative pursuit & 4.14 \\
\hline
\end{tabular}

When comparing what respondents considered important with how often respondents engage in those activities, the results are consistent. When asked how frequently they engage in these activities, respondents were given five choices from "A great deal" (value $=5$ ) to "Not at all" (value =1). The middle three values were "Quite a bit" (value =4), "Somewhat" (value = 3), and "Very little" (value =2). As there is not negative frequency, the authors used a unipolar five-point scale. The choices were presented at the top of a matrix table with increasing values from left to right. The endpoints of the response scale are maximally differentiated. The authors adhered to the common Likert scale practice of assigning "Quite a bit" a lower value than "A great deal."23

A higher mean value indicates that respondents engage more frequently in the activity. Out of the seven activities, "Living consistently with my values and beliefs" 
has the highest mean value (3.98), followed closely by "Eating healthy" (3.83), and "Challenging my mind with intellectual and creative pursuit" (3.75). The activity with the lowest mean value is Giving (such as contribute to the common welfare of our community, live in harmony with others; donating time, money, talent; practicing kindness) (3.18). This distribution is shown in figure 7.

\begin{tabular}{|c|l|c|c|c|c|c|c|c|}
\hline \multicolumn{7}{|c|}{ How frequently do you engage in these activities? } \\
\hline \# & \multicolumn{1}{|c|}{ Question } & $\begin{array}{c}\text { Not } \\
\text { at All }\end{array}$ & $\begin{array}{c}\text { Very } \\
\text { Little }\end{array}$ & Somewhat & $\begin{array}{c}\text { Quite } \\
\text { a Bit }\end{array}$ & $\begin{array}{c}\text { A Great } \\
\text { Deal }\end{array}$ & Response & $\begin{array}{c}\text { Average } \\
\text { Value }\end{array}$ \\
\hline 1 & Eating healthy & 4 & 48 & 310 & 405 & 243 & 1,010 & 3.83 \\
\hline 2 & $\begin{array}{l}\text { Exercising } \\
\text { regularly }\end{array}$ & 51 & 218 & 318 & 247 & 175 & 1,009 & 3.27 \\
\hline 3 & $\begin{array}{l}\text { Pursuing } \\
\text { continuing } \\
\text { education for } \\
\text { my career (such } \\
\text { as workshops or } \\
\text { classes) }\end{array}$ & 24 & 146 & 461 & 295 & 83 & 1,009 & 3.26 \\
\hline 4 & $\begin{array}{l}\text { Giving (for } \\
\text { instance, } \\
\text { contribute to } \\
\text { the common } \\
\text { welfare of our } \\
\text { community, live } \\
\text { in harmony with } \\
\text { others; donating } \\
\text { time, money, } \\
\text { talent; practicing } \\
\text { kindness) }\end{array}$ & 39 & 200 & 409 & 263 & 97 & 1,008 & 3.18 \\
\hline 5 & $\begin{array}{l}\text { Living } \\
\text { consistently } \\
\text { with my values } \\
\text { and beliefs }\end{array}$ & 3 & 26 & 234 & 469 & 277 & 1,009 & 3.98 \\
\hline 6 & $\begin{array}{l}\text { Being } \\
\text { optimistic }\end{array}$ & 113 & 378 & 386 & 114 & 1,008 & 3.46 \\
\hline 7 & $\begin{array}{l}\text { Challenging } \\
\text { my mind with } \\
\text { intellectual } \\
\text { and creative } \\
\text { pursuits }\end{array}$ & 7 & 49 & 341 & 400 & 212 & 1,009 & 3.75 \\
\hline
\end{tabular}

\section{Analysis of Data and Discussions}

Chi-square statistical analysis shows that there is a statistically significant relationship $\left(X^{2}(20, N=976)=0.01, P=.05\right)$ between how many hours respondents worked in a typical week and the number of full-time employees working in the respondent's library building. Respondents who work in libraries with a higher number of employees tend to work more hours in a typical week. While not captured in this study, a possible 
explanation could be that libraries with a higher number of employees are likely to be serving larger user populations, and therefore require more staff power to operate. With the trend of library budgets being stagnant or decreasing in recent years, it is very possible that larger libraries, even with a higher number of staff and librarians, are still short staffed, which results in their employees working longer hours on average. Chi-square statistical analysis shows that there is a statistically significant relationship $\left(X^{2}(20, N=1081)=0.00, P=.05\right)$ between how many hours respondents work in a typical week and how often they felt overwhelmed in the last 6 months. Respondents who work "51-60 hours" or " 60 hours or more" tend to feel overwhelmed much more frequently than respondents who work fewer hours in a typical week, including those who work a more "regular" schedule of 31-40 hours per week.
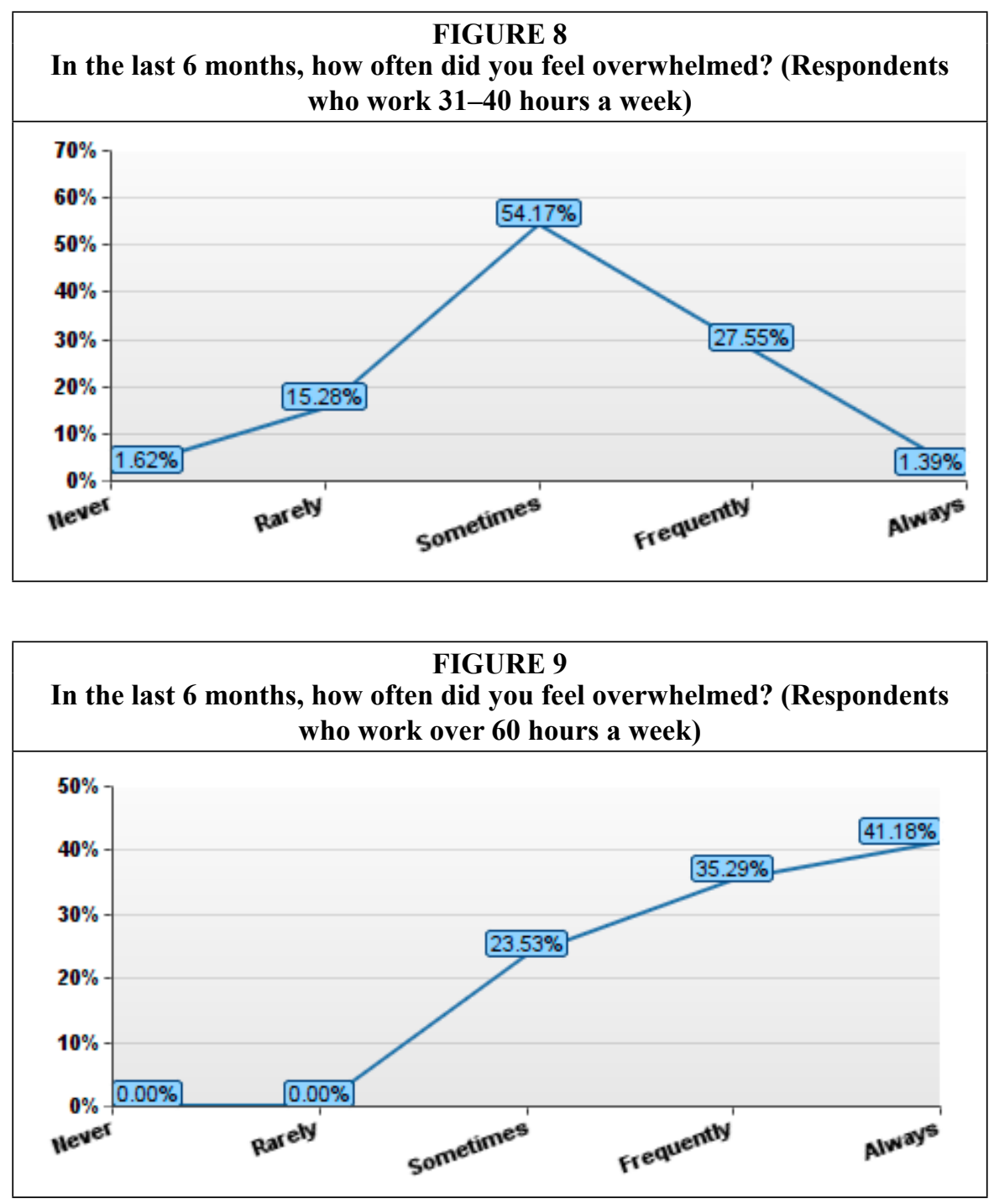
This could mean that library employees in larger libraries are more prone to feeling overwhelmed.

Chi-square statistical analysis shows that there is no statistically significant relationship $\left(X^{2}(4, N=969)=0.29, P=.05\right)$ between gender and how respondents characterize themselves (as optimistic or pessimistic); nor is there a statistically significant relationship $\left(X^{2}(4, N=969)=0.74, P=.05\right)$ between gender and how many hours respondents work in a typical week. However, Chi-square statistical analysis shows that there is a statistically significant relationship $\left(X^{2}(4, N=969)=0.00, P=.05\right)$ between gender and how often respondents felt overwhelmed in the last 6 months.
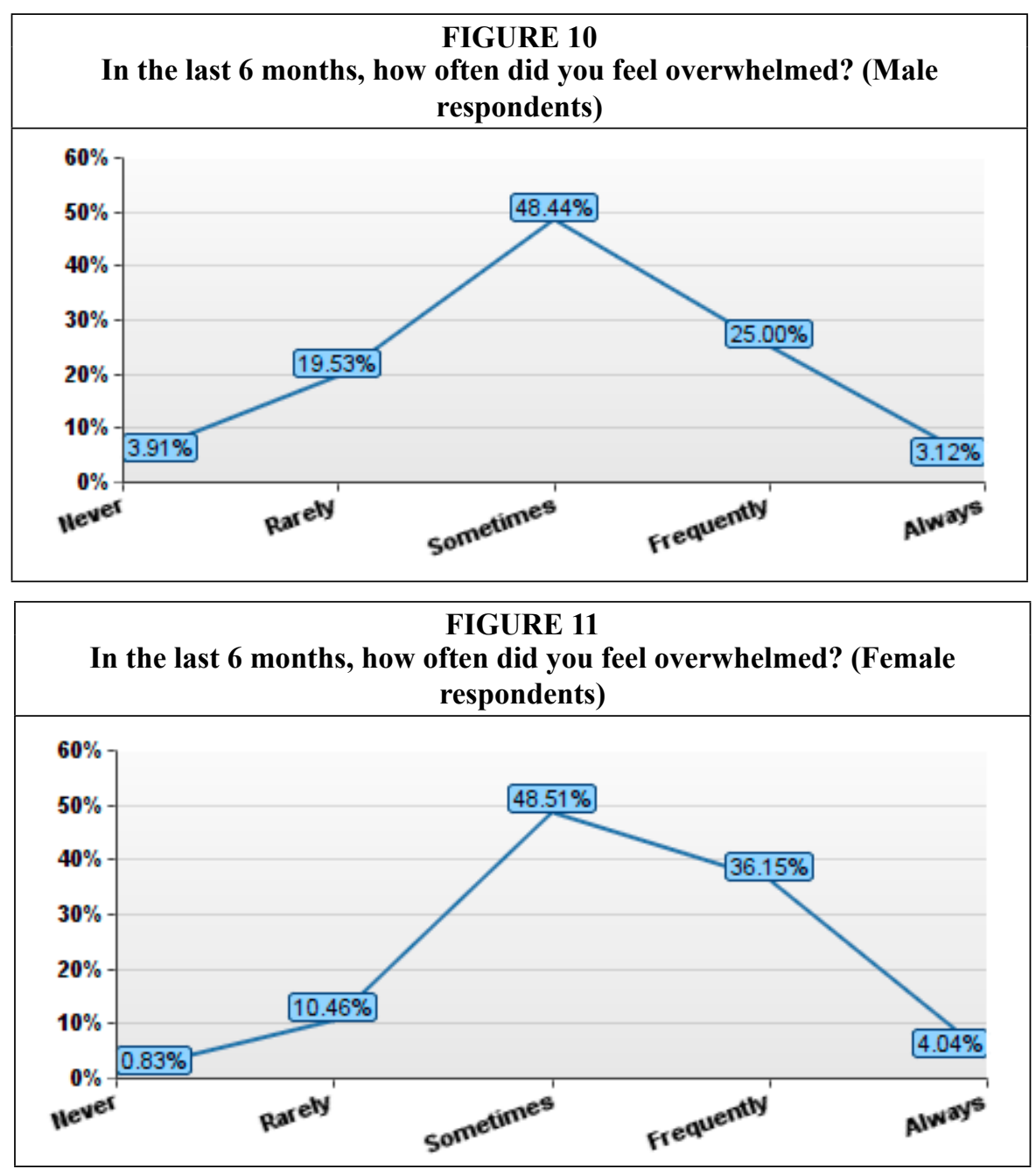

Female respondents tend to be more frequently overwhelmed in the past 6 months than male respondents. According to the survey on Stress and Gender ${ }^{24}$ from the American Psychological Association (APA), "women are more likely than men to report that their stress levels are on the rise. They are also much more likely than men to report physical and emotional symptoms of stress." In APA's data, "Almost half of 
all women (49 percent) surveyed said their stress has increased over the past five years, compared to four in 10 (39 percent) men." The difference of the percentage is similar to the finding on academic library employees.

Chi-square statistical analysis shows that there is a statistically significant relation$\operatorname{ship}\left(X^{2}(16, N=1079)=0.00, P=.05\right)$ between how the respondents characterize themselves and how often they felt overwhelmed in the last 6 months. The pattern suggests that the more optimistic respondents tend to feel overwhelmed less frequently than the pessimistic respondents.
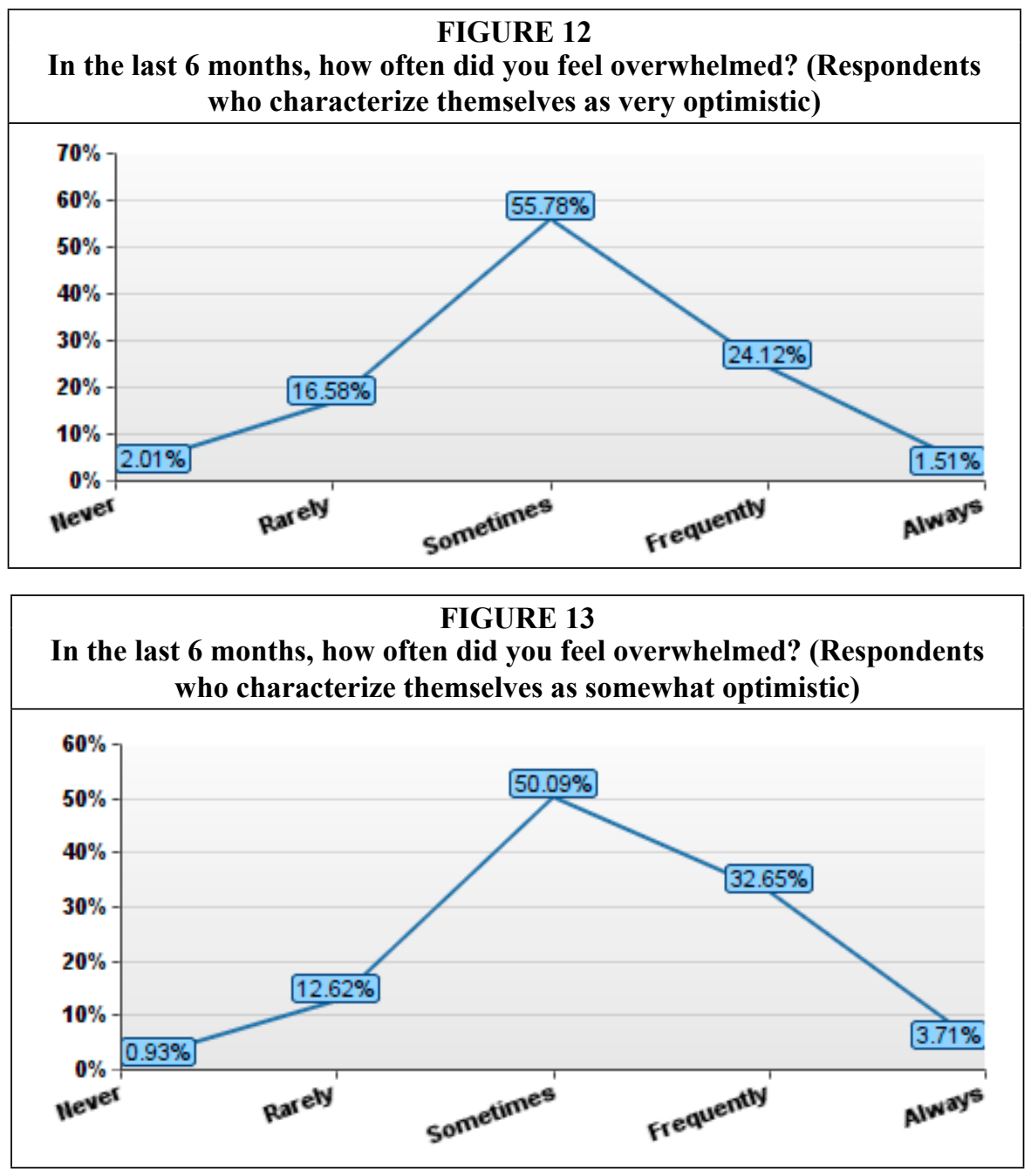

While this finding could suggest that a positive attitude could have a positive effect on countering stress or feeling overwhelmed, it is also possible that respondents were more optimistic because they felt less stress in their work or in general.

Chi-square statistical analysis also shows that there is a statistically significant relationship $\left(X^{2}(16, \mathrm{~N}=969)=0.02, P=.05\right)$ between respondents' ages and how often they felt overwhelmed in the last 6 months. The pattern indicates that respondents 

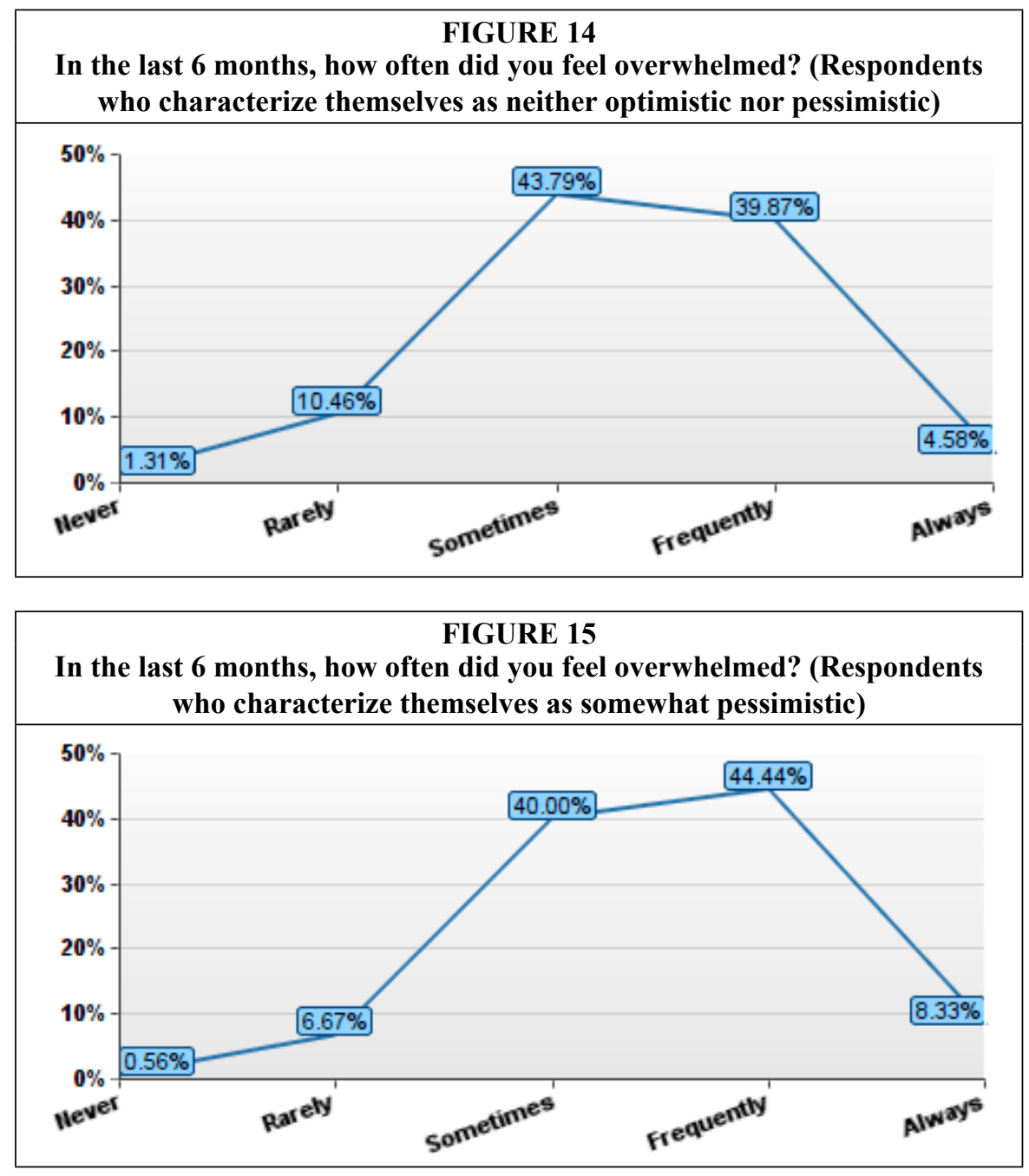

"56 years and older" tend to feel overwhelmed less frequently than respondents in the "26-35" and "36-45" age ranges. There is also a statistically significant relationship $\left(X^{2}(16, N=969)=0.00, P=.05\right)$ between respondents' ages and how they characterize themselves. Respondents in the "26-35" and " $36-45$ " age groups tend to be more pessimistic overall than the other age groups.

There is a statistically significant relationship $\left(X^{2}(20, \mathrm{~N}=969)=0.00, P=.05\right)$ between respondents' ages and how many hours they spend on work in a typical week. However, even though a higher percentage of respondents " 56 years old and over" work more than 41 hours a week than the other age groups, the group as a whole felt overwhelmed less frequently than the younger groups. These two findings are also consistent with the online survey of 2,020 U.S. adults, conducted in 2013 by Harris Interactive for APA, which finds that the Millennials generation (aged 18-33) reported higher than average stress. The APA survey finds that 19 percent of Millennials have been told they have depression, compared with 14 percent of Generation Xers (ages 34-47); 12 percent of Baby Boomers (ages 48-66) and 11 percent of those ages 67 and older. ${ }^{25}$ 
These relationships could suggest several possible causes:

1) Respondents work longer hours because their workload is heavier than others and need more time to complete their work. Respondents who are younger might be more aggressive in taking on more work, as they are either at the beginning or the prime of their careers. A higher workload is therefore the main cause of their feeling overwhelmed. This reasoning could also explain why the oldest group, who worked longer hours than other groups, did not feel overwhelmed as frequently as some other groups.

2) Respondents work longer hours because they are not as productive as others and find it difficult to complete their work in the regular work hours; therefore, they have to work longer hours. Younger respondents might be less proficient in their work at the earlier stages of their career and are still learning. They feel overwhelmed because of their lack of competency. Applied to the oldest group, who might possibly be the most experienced, this reasoning could also explain why they did not feel overwhelmed as often.

3) Respondents work longer hours because they feel obligated to be at work or doing work outside regular work hours. Younger respondents who are at earlier stages of their career might want to impress their supervisors by working longer hours. The perception of obligation is therefore the main cause of feeling overwhelmed in this scenario. Future studies could ask more in-depth questions on causes of respondents feeling overwhelmed.

In terms of how respondents value the different dimensions of wellness, Chi-square statistical analysis shows that there is a statistically significant relationship $\left(X^{2}(16, \mathrm{~N}=\right.$ $969)=0.03, P=.05$ ) between respondents' ages and how important is "Eating Healthy" (physical wellness) to them. A much higher percentage of respondents in the " 56 and over" age group viewed it as "very important" than other age groups, while the two youngest age groups ( 25 and under, and 26-35) have the lowest percentage of respondents selecting "very important" as their answers. However, there is no statistically significant relationship $\left(X^{2}(16, \mathrm{~N}=963)=0.22, P=.05\right)$ between respondents' ages and how frequently they engage in "Eating Healthy." As people age, it makes sense to be more aware of the importance of a healthy diet. However, since there is no statistically significant relationship between respondents' ages and how frequently they actually eat healthy, it could be said that simply having the awareness of the importance of a healthy diet does not necessarily translate to the behavior of eating healthy.

There are also significant statistical relationships between age and "Pursuing continuing education for my career" $\left(X^{2}(16, \mathrm{~N}=969)=0.00, P=.05\right) ;$ "Giving" $\left(X^{2}(16, \mathrm{~N}\right.$ $=969)=0.00, P=.05)$; "Being Optimistic" $\left(X^{2}(16, \mathrm{~N}=966)=0.00, P=.05\right)$. The younger respondents tend to place more importance on pursuing continued education for their career than their older colleagues, which makes sense as the younger respondents are likely to be in the growth period of their careers. Respondents in the "26-35" and "36-45" age groups have the lowest percentage of people selecting "Very Important" for "Giving." The same two age groups also tend to place less importance in "Being Optimistic." One interpretation of this finding is that the age groups might not have the financial security to allow them to "give" at this stage of their lives. From starting and/or raising families, to possibly not commanding high salaries at this stage of their lives, it is also understandable to not feeling optimistic or placing a lot of importance on the giving dimension of wellness.

\section{Conclusions and Future Directions}

This study reveals that most academic library employees feel overwhelmed quite frequently. While age and working overtime are factors, the attitude of the individual 
also has an impact. Work is the number one cause of respondents feeling overwhelmed. When respondents felt overwhelmed, they tended to "Eat More," "Avoid Social Interactions," "Watch TV/Movies," "Eat Less Healthy," and "Sleep Less." Age again seems to be an important factor regarding respondents' perception of the different dimensions of wellness. It could be argued that people in different stages of their lives place different values on the different dimensions of wellness. For example, younger respondents tend to value continuing education more than their older counterparts do, and the older respondents place more importance on eating healthy than their younger colleagues do. Overall, respondents placed higher importance on their spiritual wellness and intellectual wellness than physical wellness.

Further research into what affects academic library employee wellness can include an examination of the different types of academic libraries. Does the Carnegie Classification of Institutions of Higher Education (that is, Research University versus community college) have an impact on perceptions and attitudes toward wellness? For Professional Librarians, does faculty status (tenure vs. non-tenure track) or academic professional/staff status have an impact on wellness? What relationship does the student to librarian or student to library worker ratio have on academic library employee wellness? Additional investigation of this nature could prove valuable for academic libraries and institutions of Higher Education as employers to develop programs and policies to support employee wellness.

As this study suggests, library employees value more than just the physical aspect of wellness. The next step for the researchers will be to explore the potential of workplace wellness programs that cater to multiple dimensions of wellness by analyzing the data collected in the survey on the types of workplace wellness programs offered by the respondents' employers and the types of workplace wellness programs respondents would personally be interested in. Additional research would need to be conducted on workplace wellness efforts in both libraries and other industries that extend benefiting employees beyond physical wellness. The results of this study are important to academic libraries because they show that simply focusing on the physical aspect of wellness may not be the most effective way to support library employees. With the knowledge that library employees highly value living consistently with their values and beliefs, libraries could positively affect their employees' spiritual wellness by creating shared visions, paying attention to their motivation, personal life vision, and career goals. In addition, library employees value challenging their minds with intellectual and creative pursuits. Libraries could provide suitable professional development opportunities and support to help positively affect intellectual wellness as well.

\section{Bibliography}

Ardell, D.B. “The History and Future of Wellness." Health Values 9, no. 6 (1985): 37-56.

Beehr, Terry A. "Perceived Situational Moderators of the Relationship between Subjective Role

Ambiguity and Role Strain." Journal of Applied Psychology 61, no. 1 (1976): 35-40. doi:10.1037//0021-9010.61.1.35.

Benjamin, Michael. "The Quality of Student Life: Toward a Coherent Conceptualization." Social Indicators Research 31, no. 3 (1994): 205-64. doi:10.1007/bf01078209.

Dejoy, M., and J. Southern. "An Integrative Perspective on Work-site Health Promotion." Journal of Occupational Medicine 35, no. 12 (1993): 1221-29.

Farrell, A., and P. Geist-Martin. “Communicating Social Health: Perceptions of Wellness at Work." Management Communication Quarterly 18, no. 4 (2005): 543-92.

Greiner, P.A. "Nursing and Worksite Wellness: Missing the Boat." Holistic Nursing Practice 2, no. 1 (1987): 53-60. 
Hattie, John A., Jane E. Myers, and Thomas J. Sweeney. "A Factor Structure of Wellness: Theory, Assessment, Analysis, and Practice." Journal of Counseling and Development 82, no. 3 (2004): 354.

Hermon, David A., and Richard J. Hazler. "Adherence to a Wellness Model and Perceptions of Psychological Well-Being." Journal of Counseling $\mathcal{E}$ Development 77, no. 3 (1999): 339-43. doi:10.1002/j.1556-6676.1999.tb02457.x.

Hettler, Bill. "Wellness Promotion on a University Campus." Family \& Community Health 3, no. 1 (1980): 77-95.

Hinchliffe, Lisa J., and Melissa A. Wong. “From Services-Centered to Student-Centered: A 'Wellness Wheel' Approach to Developing the Library as an Integrative Learning Commons." College \& Undergraduate Libraries 17, no. 2/3 (2010): 213-24.

Jarvis, Cheryl Burke, Scott B. Mackenzie, and Philip M. Podsakoff. "A Critical Review of Construct Indicators and Measurement Model Misspecification in Marketing and Consumer Research." Journal of Consumer Research 30, no. 2 (2003): 199-218. doi:10.1086/376806.

Johnson, Thomas W., and John E. Stinson. "Role Ambiguity, Role Conflict, and Satisfaction: Moderating Effects of Individual Differences." Journal of Applied Psychology 60, no. 3 (1975): 329-33. doi:10.1037/h0076752.

“Librarians 'Suffer Most Stress'." BBC News (January 12, 2006). http://news.bbc.co.uk/2/ hi/uk/4605476.stm.

Mattke, Soeren, et al. (2013). Workplace Wellness Programs Study. www.nexgenhce.com/ images/RAND_Wellness_Study_-_May_2013.pdf.

Mills, John, and Damian Lodge. "Affect, Emotional Intelligence and Librarian-User Interaction." Library Review 55, no. 9 (2006): 587-97.

Murray, Richard A. "Job Satisfaction of Professional and Paraprofessional Library Staff at the University of North Carolina at Chapel Hill" (master's thesis). Chapel Hill, N.C.: University of North Carolina at Chapel Hill, 1999.

O'Donnell, Michael P., and Thomas H. Ainsworth. Health Promotion in the Workplace. New York: J. Wiley, 1984.

Reardon, J. “The History and Impact of Worksite Wellness.” Nursing Economics 16, no. 3 (1998): 117-21.

Shupe, Ellen I., Stephanie K. Wambaugh, and Reed J. Bramble. "Role-related Stress Experienced by Academic Librarians." The Journal of Academic Librarianship 41, no. 3 (2015): 264-69.

"Stress and Gender." American Psychological Association. www.apa.org/news/press/ releases/stress/2010/gender-stress.pdf.

"Stress at the Workplace." WHO. www.who.int/occupational_health/topics/stressatwp/ en/.

Topper, E.F. “Stress in the Library Workplace." New Library World 108, no. 11 (2007): 561. doi:http://dx.doi.org/10.1108/03074800710838290.

Tulloch, Judith W., R.N., M.S., and Christine C. Healy, R.N., M.S. “Changing Lifestyles: A Wellness Approach." Occupational Health Nursing 30, no. 6 (1982): 13-21, 45. http:// search.proquest.com/docview/1013441719?accountid=14472.

“Typical Survey Response Scales." Society of Teaching and Learning in Higher Education (STLHE) (April 2013). www.stlhe.ca/wp-content/uploads/2013/04/SurveyResponse-Scales.pdf.

Westgate, Charlene E. "Spiritual Wellness and Depression." Journal of Counseling $\mathcal{E}$ Development 75, no. 1 (September 1996): 26-35.

Zula, Ken. "Workplace Wellness Programs: A Comparison between Best Practice Guidelines and Implementation." JABR Journal of Applied Business Research (JABR) 30, no. 3 (2014): 783. doi:10.19030/jabr.v30i3.8564. 


\section{Appendix A. \\ E-mail listservs:}

1. COLLIB-L@lists.ala.org (ACRL's College Libraries section)

2. rusa-1@lists.ala.org (Reference \& User Services Association)

3. scholcomm@lists.ala.org (ACRL Scholarly Communication)

4. uls-1@lists.ala.org (ACRL's University Libraries section)

5. nmrt-l@lists.ala.org (ALA New Members Round Table Discussion Listserv)

6. acr-igts@lists.ala.org (ACRL Technical Services Interest Group)

7. acrlassessdg@lists.ala.org (ACRL Assessment Discussion Group)

8. nps-1@lists.ala.org (LLAMA NPS Discussion List)

9. libadmin@lists.ala.org (LLAMA Administrator List)

10. Black Caucus of the American Library Association (BCALA) listserv

11. APALA-L@lsv.uky.edu (Asian/Pacific American Librarians Association [APALA] listserv)

\section{Facebook pages:}

1. ALA Think Tank

2. University Libraries Section of ACRL

3. New Members Round Table

4. Lifting Librarians

\section{Appendix B. Work/Life Survey for Academic Librarians}

Q1 Work/Life Survey for Academic Libraries

Overview: We are conducting this survey to learn more about the perceptions and behaviors of people who work academic libraries in the concept of work/life quality and wellness. If you decide to participate, you will take a survey that should take approximately 10 minutes to complete.

Incentive for Participation: The survey provides you the option to provide your e-mail address to enter a drawing for one of two \$25 Amazon gift certificates.

Discomfort/Risks: There are no anticipated risks of participating in this study beyond what you would encounter in everyday life. Please feel free to skip any items that you feel are objectionable or that make you feel uncomfortable. You may also stop your participation in the study at any time.

Confidentiality: The researchers may publish the results of the study. If they do, they will only discuss group results. Your name and/or e-mail will not be used in any publication or presentation about the study.

Contact: If you have any questions or concerns about this study, you can contact us at: Leo Lo at leolo@ua.edu or Bethany Tschaepe at tschaepeb@uhd.edu. You are under no obligation to participate in this study.

Clicking the "Next" button below indicates that: you have read the information provided above (or have had someone read the information to you); you are aware that this is a research study; you have voluntarily agreed to participate in the study. You may print this page as your copy of the Consent Form or contact us to have a copy of the Consent Form e-mailed to you. 
Q2 At which type of institution do you work?

$\square \quad$ 2-year academic (1)

4-year academic (2)

$\square \quad$ Other academic (3)

Non-academic (4)

If Nonacademic Is Selected, Then Skip to: At this time we are focusing on acade...

Q37 How would you characterize yourself?

$\square \quad$ Very pessimistic (1)

$\square \quad$ Somewhat pessimistic (2)

$\square \quad$ Neither pessimistic nor optimistic (4)

$\square \quad$ Somewhat optimistic (5)

$\square \quad$ Very optimistic (3)

Q34 In a typical week, how many hours do you spend on work?
$\quad 0-20(1)$
口 21-30 (2)
$\square \quad 31-40(3)$
$\quad 41-50(4)$
51-60 (5)
$\square \quad 61$ and more (6)

Q5 In the last 6 months, how often did you feel overwhelmed?
$\square \quad$ Never (1)
$\square \quad$ Rarely (2)
$\square \quad$ Sometimes (3)
$\square \quad$ Frequently (4)
$\square \quad$ Always (5)

Q35 What typically overwhelms you? Please rank by arranging the following options (1 being the most overwhelming)

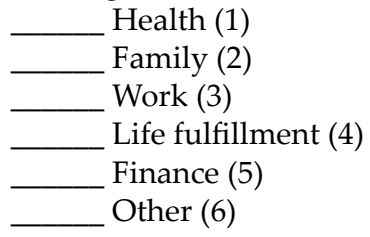

Q4 When I feel overwhelmed. I tend to (check all that apply):

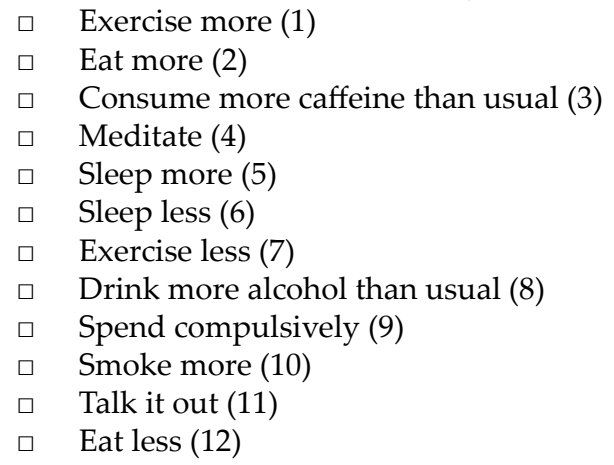




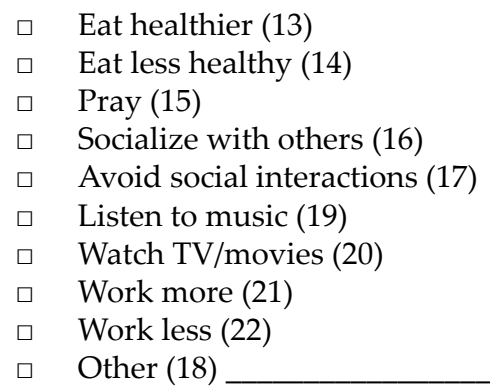

Q26 How important are these activities to you?

\begin{tabular}{|l|c|c|c|c|c|}
\hline & $\begin{array}{c}\text { Not Very } \\
\text { Important } \\
\text { (1) }\end{array}$ & $\begin{array}{c}\text { Somewhat } \\
\text { Important } \\
\text { (2) }\end{array}$ & $\begin{array}{c}\text { Moderately } \\
\text { Important } \\
\text { (3) }\end{array}$ & $\begin{array}{c}\text { Important } \\
\text { (4) }\end{array}$ & $\begin{array}{c}\text { Very } \\
\text { Important } \\
\text { (5) }\end{array}$ \\
\hline Eating healthy (1) & $\square$ & $\square$ & $\square$ & $\square$ & $\square$ \\
\hline Exercising regularly (2) & $\square$ & $\square$ & $\square$ & $\square$ & $\square$ \\
\hline $\begin{array}{l}\text { Pursuing continuing } \\
\text { education for my career } \\
\text { (such as workshops or } \\
\text { classes) (3) }\end{array}$ & $\square$ & $\square$ & $\square$ & $\square$ & $\square$ \\
\hline $\begin{array}{l}\text { Giving (for instance, } \\
\text { contribute to the } \\
\text { common welfare of } \\
\text { our community, live in } \\
\text { harmony with others; } \\
\text { donating time, money, } \\
\text { talent; practicing } \\
\text { kindness) (4) }\end{array}$ & $\square$ & $\square$ & $\square$ & $\square$ & $\square$ \\
\hline $\begin{array}{l}\text { Living consistently } \\
\text { with my values and } \\
\text { beliefs (5) }\end{array}$ & $\square$ & $\square$ & $\square$ & $\square$ & $\square$ \\
\hline Being optimistic (6) & $\square$ & $\square$ & $\square$ & $\square$ & $\square$ \\
\hline $\begin{array}{l}\text { Challenging my mind } \\
\text { with intellectual and } \\
\text { creative pursuit (7) }\end{array}$ & $\square$ & $\square$ & $\square$ & & $\square$ \\
\hline
\end{tabular}

Q29 How frequently do you engage in these activities?

\begin{tabular}{|l|c|c|c|c|c|}
\hline & $\begin{array}{c}\text { Not at } \\
\text { All (1) }\end{array}$ & $\begin{array}{c}\text { Very } \\
\text { Little (2) }\end{array}$ & $\begin{array}{c}\text { Somewhat } \\
\text { (3) }\end{array}$ & $\begin{array}{c}\text { Quite a } \\
\text { Bit (4) }\end{array}$ & $\begin{array}{c}\text { A Great } \\
\text { Deal (5) }\end{array}$ \\
\hline Eating healthy (1) & $\square$ & $\square$ & $\square$ & $\square$ & $\square$ \\
\hline Exercising regularly (2) & $\square$ & $\square$ & $\square$ & $\square$ & $\square$ \\
\hline $\begin{array}{l}\text { Pursuing continuing } \\
\text { education for my career } \\
\text { (such as workshops or } \\
\text { classes) (3) }\end{array}$ & $\square$ & $\square$ & $\square$ & $\square$ & $\square$ \\
\hline
\end{tabular}




\begin{tabular}{|l|c|c|c|c|c|}
\hline $\begin{array}{l}\text { Giving (for instance, } \\
\text { contribute to the common } \\
\text { welfare of our community, } \\
\text { live in harmony with others; } \\
\text { donating time, money, talent; } \\
\text { practicing kindness) (4) }\end{array}$ & $\square$ & $\square$ & $\square$ & $\square$ & $\square$ \\
\hline $\begin{array}{l}\text { Living consistently with my } \\
\text { values and beliefs (5) }\end{array}$ & $\square$ & $\square$ & $\square$ & $\square$ & $\square$ \\
\hline Being optimistic (6) & $\square$ & $\square$ & $\square$ & $\square$ & $\square$ \\
\hline $\begin{array}{l}\text { Challenging my mind with } \\
\text { intellectual and creative } \\
\text { pursuits (7) }\end{array}$ & $\square$ & $\square$ & $\square$ & $\square$ & $\square$ \\
\hline
\end{tabular}

Q8 To what extent do you agree or disagree with the following statements regarding your workplace?

\begin{tabular}{|l|c|c|c|c|c|}
\hline & $\begin{array}{c}\text { Strongly } \\
\text { Disagree } \\
\text { (1) }\end{array}$ & $\begin{array}{c}\text { Disagree } \\
\text { (2) }\end{array}$ & $\begin{array}{c}\text { Neither } \\
\text { Agree Nor } \\
\text { Disagree (3) }\end{array}$ & $\begin{array}{c}\text { Agree } \\
\text { (4) }\end{array}$ & $\begin{array}{c}\text { Strongly } \\
\text { Agree } \\
\text { (5) }\end{array}$ \\
\hline $\begin{array}{l}\text { My workplace promotes work/ } \\
\text { life balance (1) }\end{array}$ & $\square$ & $\square$ & $\square$ & $\square$ & $\square$ \\
\hline $\begin{array}{l}\text { I feel supportive in my work } \\
\text { environment (2) }\end{array}$ & $\square$ & $\square$ & $\square$ & $\square$ & $\square$ \\
\hline $\begin{array}{l}\text { I have a sense of accomplishment } \\
\text { in my position (3) }\end{array}$ & $\square$ & $\square$ & $\square$ & $\square$ & $\square$ \\
\hline $\begin{array}{l}\text { I feel empowered to make a } \\
\text { positive impact in my work } \\
\text { environment (4) }\end{array}$ & $\square$ & $\square$ & $\square$ & $\square$ & $\square$ \\
\hline $\begin{array}{l}\text { I am hopeful of the future } \\
\text { direction of my workplace (5) }\end{array}$ & $\square$ & $\square$ & $\square$ & $\square$ & $\square$ \\
\hline
\end{tabular}

Q6 Does your workplace offer any wellness programs for employees?

$\square \quad$ Yes, both my library and my institution offer wellness programs for employees (1)

$\square \quad$ Yes, only my institution offers wellness programs for employees (2)

$\square \quad$ Yes, only my library offers wellness programs for employees (3)

$\square \quad$ No, neither my library nor my institution offers wellness programs for employees (4)

Answer: If Does your workplace offer any wellness programs for employees? Yes, both my library and my institution offer wellness programs for employees Is Selected Or Does your workplace offer any wellness programs for employees? Yes, only my library offers wellness programs for employees Is Selected

Q7 What type of wellness program does your library offer for employees?

Answer: If Does your workplace offer any wellness programs for employees? Yes, both my library and my institution offer wellness programs for employees Is Selected Or Does your workplace offer any wellness programs for employees? Yes, only my institution offers wellness programs for employees Is Selected 
Q36 What type of wellness program does your institution offer for employees?

Q19 What type of wellness program would you personally be interested in?

Q10 To what extent do you agree or disagree with the following statements?

\begin{tabular}{|l|c|c|c|c|c|}
\hline & $\begin{array}{c}\text { Strongly } \\
\text { Disagree } \\
\text { (1) }\end{array}$ & $\begin{array}{c}\text { Disagree } \\
\text { (2) }\end{array}$ & $\begin{array}{c}\text { Neither } \\
\text { Agree Nor } \\
\text { Disagree (3) }\end{array}$ & $\begin{array}{c}\text { Agree } \\
\text { (4) }\end{array}$ & $\begin{array}{c}\text { Strongly } \\
\text { Agree } \\
\text { (5) }\end{array}$ \\
\hline $\begin{array}{l}\text { My library should provide } \\
\text { services to improve our users' } \\
\text { wellness. (1) }\end{array}$ & $\square$ & $\square$ & $\square$ & $\square$ & $\square$ \\
\hline $\begin{array}{l}\text { My library should provide space } \\
\text { to improve our users' wellness. (2) }\end{array}$ & $\square$ & $\square$ & $\square$ & $\square$ & $\square$ \\
\hline $\begin{array}{l}\text { Improving our users' wellness } \\
\text { will improve their academic } \\
\text { performance. (3) }\end{array}$ & $\square$ & $\square$ & $\square$ & $\square$ & $\square$ \\
\hline $\begin{array}{l}\text { Students often seem stressed in } \\
\text { the library. (4) }\end{array}$ & $\square$ & $\square$ & $\square$ & $\square$ & $\square$ \\
\hline $\begin{array}{l}\text { My library partners with other } \\
\text { campus organizations to improve } \\
\text { the wellness of our users. (5) }\end{array}$ & $\square$ & $\square$ & $\square$ & $\square$ & $\square$ \\
\hline $\begin{array}{l}\text { My library promotes our wellness } \\
\text { resources to our users. (6) }\end{array}$ & $\square$ & $\square$ & $\square$ & $\square$ & $\square$ \\
\hline
\end{tabular}

Q21 What is your current position?

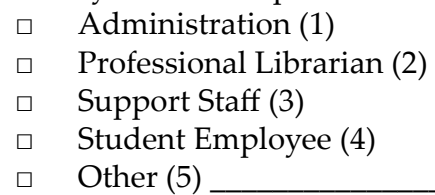

Q33 How many full-time library employees work in the library building where you work? If you are not certain, please estimate.

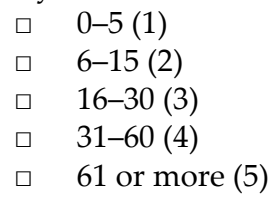

Q26 What is your gender?
Male (1)
$\square \quad$ Female (2)

Q27 What is your age?
$\square \quad 25$ and under (1)
ㅁ 26-35 (2)
36-45(3)
46-55 (4)
$\square \quad 56$ and over (5) 
Q39 How long have you worked in libraries?

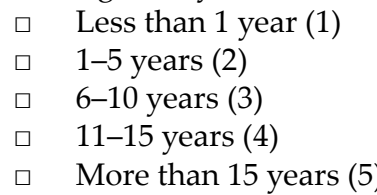

Q30 If you would like to be entered in a drawing for one of two \$25 Amazon Gift Certificates, please provide your e-mail address in the box below.

Q32 Thank you for completing our survey! We plan to share the results of this survey with librarians through conference presentations and/or publications. If you have any questions or additional comments about the survey or if you would like to request a copy of the results or be informed about presentations or publications based on the results, please contact any of the following individuals: Leo Lo at leolo@ua.edu, Bethany Tschaepe at tschaepeb@uhd.edu.

If Thank you for completing ou... Is Displayed, Then Skip to End of Survey

Q31 At this time we are focusing on academic 2-year and 4-year institutions! We plan to share the results of this survey with librarians through conference presentations and/ or publications. If you have any questions or additional comments about the survey or if you would like to request a copy of the results or be informed about presentations or publications based on the results, please contact any of the following individuals: Leo Lo at leolo@ua.edu, Bethany Tschaepe at tschaepeb@uhd.edu.

If At this time we are focusin... Is Displayed, Then Skip to End of Survey

\section{Notes}

1. Terry A. Beehr, "Perceived Situational Moderators of the Relationship between Subjective Role Ambiguity and Role Strain," Journal of Applied Psychology 61, no. 1 (1976): 35-40, doi:10.1037//0021-9010.61.1.35; Thomas W. Johnson and John E. Stinson, "Role Ambiguity, Role Conflict, and Satisfaction: Moderating Effects of Individual Differences," Journal of Applied Psychology 60, no. 3 (1975): 329-33, doi:10.1037/h0076752.

2. "Stress at the Workplace," WHO, available online at www.who.int/occupational_health/ topics/stressatwp/en/ [accessed 5 May 2016].

3. J. Reardon, "The History and Impact of Worksite Wellness," Nursing Economics 16, no. 3 (1998): 117-21, available online at CINAHL Plus with Full Text, EBSCOhost [accessed 1 May 2016].

4. Ken Zula, "Workplace Wellness Programs: A Comparison between Best Practice Guidelines and Implementation," JABR Journal of Applied Business Research (JABR) 30, no. 3 (2014): 783. doi:10.19030/jabr.v30i3.8564.

5. Soeren Mattke et al., Workplace Wellness Programs Study (2013), available online at www. nexgenhce.com/images/RAND_Wellness_Study_-_May_2013.pdf [accessed 9 May 2016].

6. Reardon, "The History and Impact of Worksite Wellness."

7. David A. Hermon and Richard J. Hazler, "Adherence to a Wellness Model and Perceptions of Psychological Well-Being," Journal of Counseling $\mathcal{E}$ Development 77, no. 3 (1999): 339-43, doi:10.1002/j.1556-6676.1999.tb02457.x; D.B. Ardell, “The History and Future of Wellness," Health Values 9, no. 6 (1985): 37-56; Michael Benjamin, "The Quality of Student Life: Toward a Coherent Conceptualization," Social Indicators Research 31, no. 3 (1994): 205-64, doi:10.1007/bf01078209.

8. M. Dejoy and J. Southern, "An Integrative Perspective on Work-site Health Promotion," Journal of Occupational Medicine 35, no. 12 (1993): 1221-29.

9. P.A. Greiner, "Nursing and Worksite Wellness: Missing the Boat," Holistic Nursing Practice 2, no. 1 (1987): 53-60, available online at CINAHL Plus with Full Text, EBSCOhost [accessed 1 May 2016]. 
10. Michael P. O'Donnell and Thomas H. Ainsworth, Health Promotion in the Workplace (New York: J. Wiley, 1984).

11. Judith W. Tulloch and Christine C. Healy, "Changing Lifestyles: A Wellness Approach," Occupational Health Nursing 30, no. 6 (1982): 13-21, 45, available online at http://search.proquest.com/ docview/1013441719?accountid=14472 [accessed 9 May 2016]; Charlene E. Westgate, "Spiritual Wellness and Depression," Journal of Counseling \& Development 75, no. 1 (Sept. 1996): 26-35, available online at Business Source Complete, EBSCOhost [accessed 9 May 2016]; A. Farrell and P. Geist-Martin, "Communicating Social Health: Perceptions of Wellness at Work," Management Communication Quarterly: McQ 18, no. 4 (2005): 543-92, available online at http://search.proquest. com/docview/216340706? accountid=14472 [accessed 9 May 2016].

12. "Librarians 'Suffer Most Stress'," BBC News (Jan. 12, 2006), available online at http://news. bbc.co.uk/2/hi/uk/4605476.stm [accessed 9 May 2016].

13. E.F. Topper, "Stress in the Library Workplace," New Library World 108, no. 11 (2007): 561, doi:http://dx.doi.org/10.1108/03074800710838290.

14. L. Farler and J. Broady-Preston, "Workplace Stress in Libraries: A Case Study," Aslib Proceedings 64, no. 3 (2012): 225-40, available online at Science Citation Index, EBSCOhost [accessed 9 May 2016].

15. Ellen I. Shupe, Stephanie K. Wambaugh, Reed J. Bramble, “Role-related Stress Experienced by Academic Librarians," Journal of Academic Librarianship 41, no. 3 (2015): 265.

16. Lisa J. Hinchliffe and Melissa A. Wong, "From Services-Centered to Student-Centered: A 'Wellness Wheel' Approach to Developing the Library as an Integrative Learning Commons,' College \& Undergraduate Libraries 17, no. 2/3 (2010): 219-20.

17. John Mills and Damian Lodge, "Affect, Emotional Intelligence and Librarian-User Interaction," Library Review 55, no. 9 (2006): 588-92.

18. Richard A. Murray, "Job Satisfaction of Professional and Paraprofessional Library Staff at the University of North Carolina at Chapel Hill" (master's thesis, University of North Carolina at Chapel Hill, 1999).

19. John A. Hattie, Jane E. Myers, and Thomas J. Sweeney, "A Factor Structure of Wellness: Theory, Assessment, Analysis, and Practice," Journal of Counseling and Development 82, no. 3 (2004): 354, available online at ERIC, EBSCOhost [accessed 1 May 2016].

20. Bill Hettler, 1980. "Wellness Promotion on a University Campus," Family \& Community Health 3, no. 1 (1980): 77.

21. Hettler, "Wellness Promotion on a University Campus," 77-95.

22. Cheryl Burke Jarvis, Scott B. Mackenzie, and Philip M. Podsakoff, "A Critical Review of Construct Indicators and Measurement Model Misspecification in Marketing and Consumer Research," Journal of Consumer Research 30, no. 2 (2003): 199-218, doi:10.1086/376806.

23. Society of Teaching and Learning in Higher Education (STLHE), "Typical Survey Response Scales" (Apr. 2013), available online at www.stlhe.ca/wp-content/uploads/2013/04/SurveyResponse-Scales.pdf [accessed 22 June 2016].

24. American Psychological Association, "Stress and Gender," available online at www.apa. org/news/press/releases/stress/2010/gender-stress.pdf [accessed 27 January 2016].

25. American Psychological Association, "Stress in America: Paying with Our Health" (Feb. 4 , 2015), available online at www.apa.org/news/press/releases/stress/2014/stress-report.pdf [accessed 27 January 2016]. 